\title{
Aquifers Characterization and Productivity in Ellala Catchment, Tigray, Northern
} Ethiopia

\author{
Grmay Kassa $^{1}$, Nata Tadesse ${ }^{2 *}$ and Tesfamichael G/Yohannes ${ }^{2}$ \\ ${ }^{1}$ Department of Earth Science, College of Natural and Computational Sciences, Adigrat \\ University, Adigrat, Ethiopia (grmaykassa@yahoo.com). \\ ${ }^{2}$ Department of Earth Science, College of Natural and Computational Sciences, Mekelle \\ University, P.O. Box 3066, Mekelle University, Mekelle, Ethiopia (*tafesse24603@ yahoo.com)
}

\begin{abstract}
This paper assesses the aquifer characteristics and productivity nature of different rocks and sediments using geological and hydrogeological methods in Ellala catchment $\left(296.5 \mathrm{~km}^{2}\right)$ in Tigray, northern Ethiopia. The catchment consists of limestone (29.91\%), intercalation of limestone-shale-marl (27.90\%), dolerite dykes and sills (21.85\%) and recent sediments $(20.33 \%)$. Compared to rocks, the sediment due to lack of both extensive areal coverage and thickness, its water-bearing capability is almost negligible. Aquifers developed in the different rocks are mainly due to secondary processes such as weathering, fracturing and karstification. The degree of variations in the groundwater productivity is mainly linked with the variations in the effect of these processes in the respective rock. Hydrodynamic analyses of the aquifers reveal that in the limestone aquifer hydraulic conductivity is ranging from 0.046 to $4.65 \mathrm{~m} /$ day with a mean value of $1.44 \mathrm{~m} /$ day and transmissivity is ranging from 2.38 to $93.02 \mathrm{~m}^{2} /$ day with a mean value of $32.58 \mathrm{~m}^{2} /$ day; in the intercalated limestone-shale-marl aquifer hydraulic conductivity is ranging from 0.87 to $70.13 \mathrm{~m} /$ day with a mean value of $10.11 \mathrm{~m} /$ day and transmissivity is ranging from 17.88 to $645.7 \mathrm{~m}^{2} /$ day with a mean value of $163.41 \mathrm{~m}^{2} /$ day; and in the dolerite aquifer hydraulic conductivity is ranging from 1.67 to $108.86 \mathrm{~m} /$ day with a mean value of $59.32 \mathrm{~m} /$ day and transmissivity is ranging from 57.63 to $307 \mathrm{~m}^{2} /$ day with a mean value of $142.71 \mathrm{~m}^{2} /$ day. Based on these determined transmissivity values of different aquifers and geomorphological setup of the catchment, the potentiality degree of the aquifers of the catchment range from moderate to negligible. The negligible potentiality aquifer is found covering steep slopes and topographically high areas, whereas aquifers that have moderate to weak degree of potentiality are found occupying flat to rugged topography of the catchment.
\end{abstract}

Keywords: Groundwater, Aquifer, Ellala catchment, Hydraulic conductivity, Transmissivity, Ethiopia.

\section{INTRODUCTION}

Groundwater potential in Ethiopia is low compared to surface water resources. But, the total exploitable groundwater potential is high. Current estimates put the available groundwater resources in the country to be about 2.6 billion $\mathrm{m}^{3}$ (Ministry of Water Resource, 2001). An aquifer is an underground layer of water-bearing permeable rocks or unconsolidated materials from which groundwater can be extracted using water well. Aquifer characterization takes into account how the different geological formations get a water-bearing nature; how the arrangement 
of these water-bearing geological formations with adjacent impervious layer looks like and the potentiality nature of the aquifer (Şen, 1995; Nedaw, 2003). This characterization is very essential, when dealing with problems of groundwater flow and groundwater resource evaluation. In order to define the characteristics of aquifer, such as hydraulic conductivity, transmissivity etc, aquifer tests should be conducted in open holes and wells. The characterization may require the use of existing pumping test data, geologic map, hydrogeological map, soil map, and lithology obtained from well logs, aquifer thickness as well as well inventory (Singhal and Gupta, 1999; Matthess, 1982).

In designing and capturing as well as dewatering systems of groundwater, in addition to schemating the natural hydrogeological conditions, it is important to know the hydrogeological parameters. Quantitative evaluation of groundwater potential is only possible when these basic parameters are properly defined and physically related to some aquifer properties (Nata, 2003; Fetter, 2001; Mace, 1997).

Currently, in the catchment, groundwater is serving as a main water sources for both domestic water supply, industrial and livestock purposes. A number of deep wells, shallow wells, hand dug wells have been drilled in different parts of the catchment for these purposes both by government and non-governmental organizations.

Among various parts of the country, Tigray region, where the study area is located, is one of the areas that is highly affected by frequent droughts. Major climatic limitations for agricultural production are erratic rainfall, unpredictable monsoons, which often combined with intermittent dry spells that regularly threaten the survival of the crops, resulting in reduced production and food insecurity (Nata and Bheemalingeswara, 2010)

In order to reduce dependency on large amounts of assistance, the Regional Government some years ago, has formulated a "Rural Development Strategy Plan" based on water, agriculture and cooperatives. Water harvesting with ponds and groundwater extraction by shallow wells was one of its main objectives, intended to increase the agricultural production during relatively good times and secure crop production during dryer years.

The above said plan was implemented in many areas in Tigray region since 2003. Ellala is one such catchment is in Tigray region that has experienced this intervention. This resulted in drilling a number of shallow wells in rural parts of the catchment. Hand dug wells and springs are also 
used for this purpose. Even though, a number of investigations have been done in the Ellala catchment, except for few, their recharges are not estimated. Currently, in different parts of the catchment seventeen shallow wells have been drilled for irrigation purposes and more are planned to be drilled. Present paper makes use of the information provided by these drill holes; try to characterize different aquifers and determine their respective groundwater productivity.

\subsection{Description of the Study Area}

The catchment about $26.7 \mathrm{~km}$ in radius is situated around Mekelle, capital city of Tigray Regional State. Geographically, it is bounded between $13^{\circ} 27^{\prime} 8^{\prime \prime}-13^{\circ} 35^{\prime} 43^{\prime \prime} \mathrm{N}$ and $39^{\circ} 22^{\prime} 31^{\prime \prime}-$ $39^{\circ} 43^{\prime} 2^{\prime \prime} \mathrm{E}$, having an area of $296.5 \mathrm{~km}^{2}$ (Fig 1).

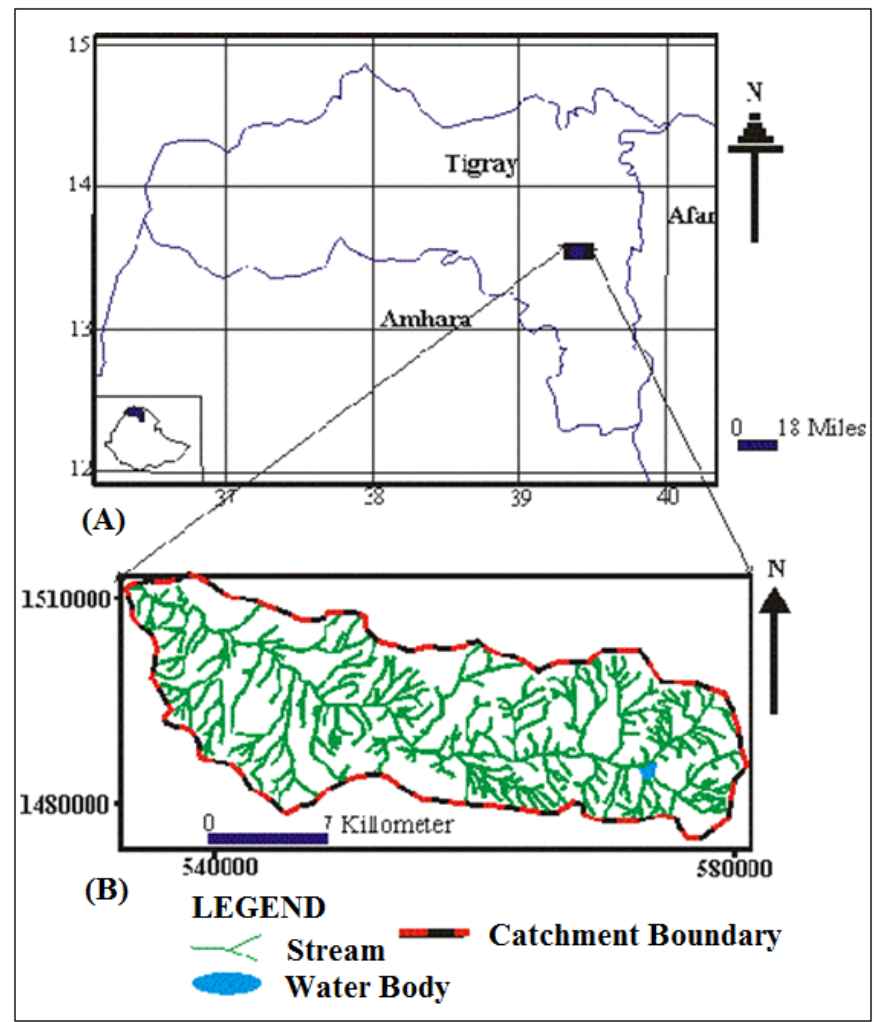

Figure 1. Location map of the catchment (Source for A: Nata et. al, 2009).

The study area is drained by Ellala, a perennial river. It originates from the northeastern highlands and flow towards northwest and finally joins the Tekeze drainage system, which is the main tributary of Atbarah River in Sudan. There are also many small intermittent tributaries of Ellala River that drain the area. These streams originate from the surrounding highlands, are dense at areas of higher slopes and sparse at relatively flat areas. The catchment drainage pattern 
is generally dendritic (Fig 1). The main river follows the structurally weak plane related to Mekelle fault which intersect different lithological units whereas the tributaries follow the general slope inclination.

The altitude of the catchment varies from 1960 m.a.s.l. at the foot of the escarpments to 2620 m.a.s.l. at eastern part of the catchment. The mean annual temperature ranges from 15 to $16^{\circ} \mathrm{C}$. The hottest month is May with a mean maximum temperature of $24.80^{\circ} \mathrm{C}$ and mean minimum temperature of $11.5^{\circ} \mathrm{C}$. The coolest month is December characterized by maximum and minimum temperature of $24.5^{\circ} \mathrm{C}$ and $11.3^{\circ} \mathrm{C}$, respectively. The catchment has two rainy seasons, March to April and June to September. Most of the annual rainfall occurs during July and August and to some extent in June and September with a mean annual rain fall about $650 \mathrm{~mm}$.

\subsection{Local Geology}

The lithological units that occur in the Ellala catchment from the oldest to the youngest are limestone, limestone-shale-marl intercalation, dolerite dykes and sill and Quaternary sediments. These units are briefly described below.

\subsubsection{Limestone}

It is a major formation outcropping in the north, northeastern and central parts of the area and covers $29.91 \%$ of the study area. It is fossiliferous and also non-fossiliferous and gray to yellow in color. In the catchment, this unit in general is found forming steep slope mountains and cliffs. It is also found underlying the young units in the flatland of the area. In some areas it is also found affected by minor and major faults, localized folds, joints, fractures, and karstic features.

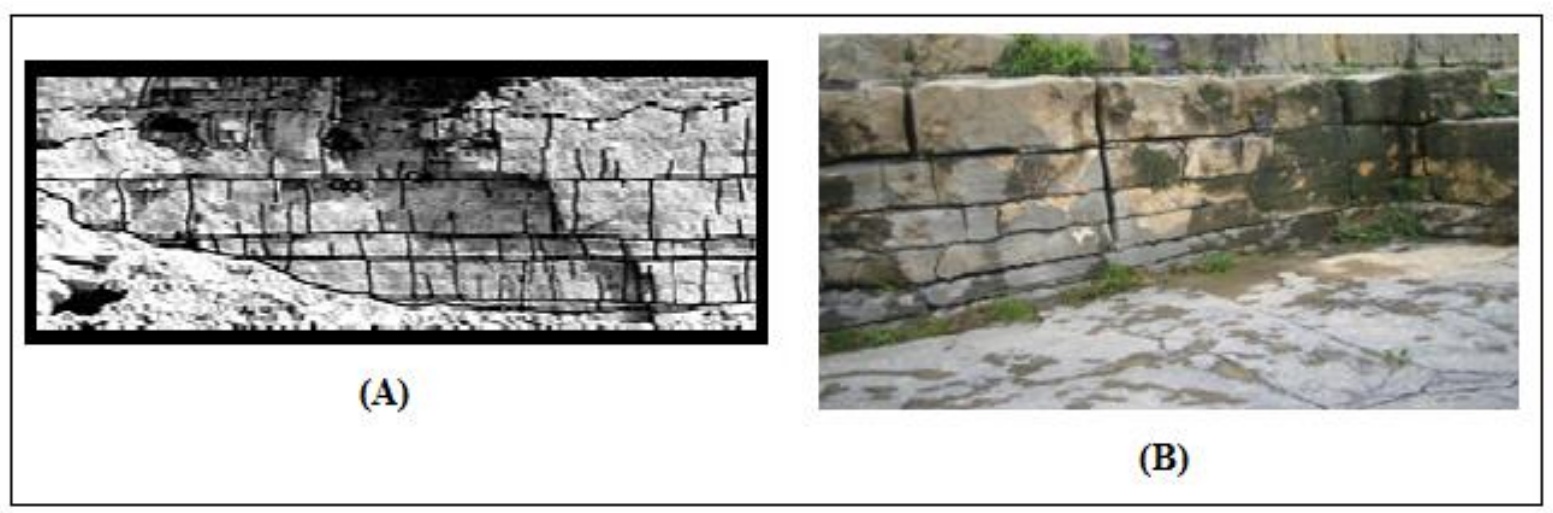

Figure 2. A) Thinly bedded and intensive laterally as well as vertical jointed limestone; B) scarcely vertical and lateral jointed and fractured limestone. 
Generally, it is a horizontal to sub-horizontal bedded formation. It has a strike of E-W and dips toward north with dip amount $10^{\circ}$ in the northern part but, in the eastern part, it shows a strike of $\mathrm{N}-\mathrm{S}$ which is horizontally bedded. In the central part of the catchment, the unit has a strike of $\mathrm{S} 88^{\circ} \mathrm{E}$ dipping to ward $\mathrm{SW}$ with dip amount ranging from $11-22^{\circ}$. The exposed vertical thickness of this unit ranges from 2 to $30 \mathrm{~m}$. Dolerite dykes and sills having different dimensions intruded this unit in various directions, mainly in the vicinity of Mekelle area, causing complete dismembering of the rock units.

\subsubsection{Limestone-Shale-Marl Intercalation}

This unit is outcropped mainly in the northwestern, southeastern, southwestern, northern and central parts of the catchment, and covers $27.90 \%$ of the total study area. It is found forming mountain that has a slope ranging from moderately steep to steep and also covering flatland areas. It is consisting of thick, light yellowish and greenish gray shale intercalated with thinly bedded, light gray to yellowish marl and thick, finely crystalline, massive, black to gray limestone. The unit is generally dominated by shale and marls in various proportions. The exposed thickness of each shale bed is ranging from 0.2 to $2 \mathrm{~m}$, and it is highly weathered. The intercalated marl, which has a thickness ranging from 0.2 to $0.5 \mathrm{~m}$, is also highly weathered. The thickness of the intercalated limestone is ranging from 0.3 to $6 \mathrm{~m}$. In some areas of the catchment, the limestone is fossiliferous, fractured and weathered. However, the fractures are very tight and non-penetrative. The orientation of the fractures is dominantly $\mathrm{N} 50^{\circ} \mathrm{W}$.

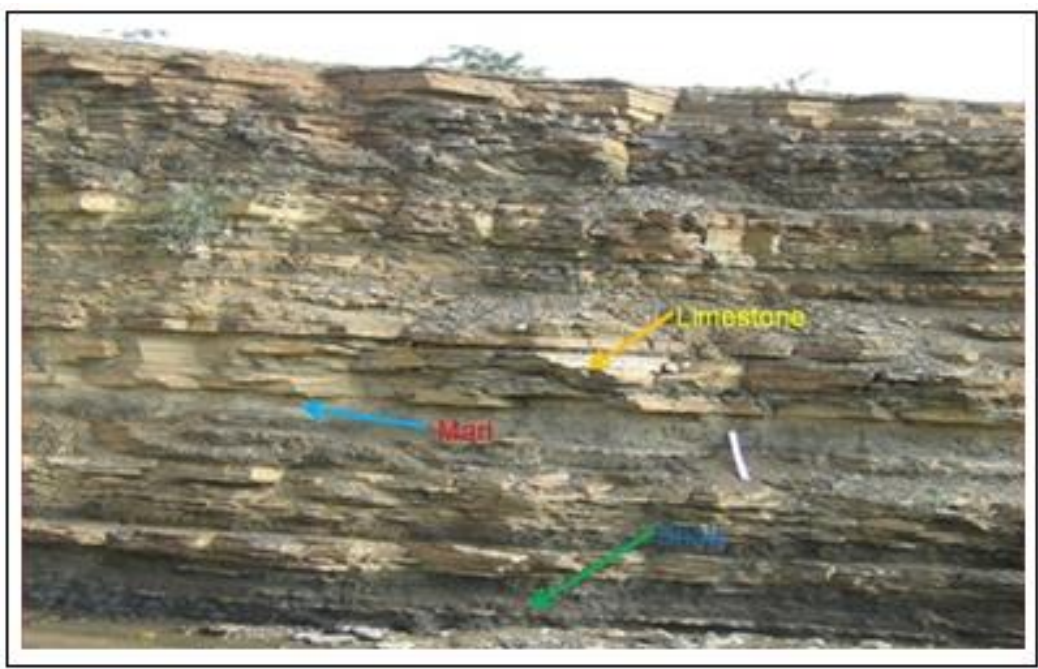

Figure 3. River bank exposure of intercalation of limestone-shale-marl. 
In northwestern part, the trend of this unit is averagely having a strike of $\mathrm{N} 25^{\circ} \mathrm{E}$ and dipping to ward southeastern with dip amount of $10^{\circ}$. In this part, the unit is also found having a strike of E$\mathrm{W}$ and dipping to ward north and south with dip amount of $25^{\circ}$ and $10^{\circ}-15^{\circ} \mathrm{N}$, respectively which forms a localized anticline fold. In the southwestern part of the catchment, where this unit is exposed, the unit has a strike of E-W and dipping toward south and north having a dip amount averagely $25^{\circ}$, and this forms a localized syncline fold. In this part the unit has also a trend with strike of $\mathrm{N} 30^{\circ} \mathrm{W}$ dipping to ward northeast with a dip amount of $15^{\circ}$.

\subsubsection{Mekelle Dolerites}

Occur as dykes and sills. They are black, andesine dolerites with ophitic texture. They usually intrude the limestone and limestone-shale-marl intercalation units of the catchment. They are comagmatic with the Trap Series volcanics (Tesfaye, 1993) and some of them being feeders for eruptions of the Trap Series. This unit is outcropped in the western, northern, northeastern, southern, southeastern and in the central parts and covers $21.85 \%$ of the total study area. They are trending N-S in the western and southwestern parts and E-W in the southern, northeastern and central parts of the catchment. They also occur as irregular bodies within the sedimentary successions in different parts of the catchment. The weathered part of this dolerite dyke exposes a circular boulder resulting from spheroidal weathering.

\subsubsection{Quaternary Deposits}

In the catchment, extensive Quaternary sediment areas are scarce. Quaternary sediments are found in limited thickness and areal extent mainly in the flat laying areas and as thin strips along the margins of the Ellala river and its tributaries. Elsewhere bedrock is variably covered by earthy soils. These deposits are exposed in the southwestern, northwestern, northeastern and southeastern parts of the catchment, and covers $20.33 \%$ of the total study area. The sediments do not have the same thickness throughout the area in which they exposed.

Less extensive unconsolidated sediments occur in the northeastern and southeastern parts of the catchment covering the relatively flat areas. These sediments are formed by the processes of weathering from the underlying bedrocks. The sediments are mainly black cotton soil which being rich in clay, and their thickness range from 2 to 4 meters, most being between 2 to $3 \mathrm{~m}$. In the catchment alluvium are found as thin strips along the margins of the Ellal River and its tributaries. These thin strips of alluvium along the margins of the Ellala River and its tributaries 
occur in most places both in the highlands and the lowlands. The relative abundances and stratigraphic relations of the sediments, however, are generally not uniform throughout the catchment. Toward the mountains front, where steep topographic slopes exist and the gradient of the rivers is high, the alluvial sediments, in general, are dominated by sub angular to sub rounded coarse grained particles with variable content of coarse grained sand. In the southwestern and northwestern parts of the catchment, where the gradient of the rivers is decreases down slope, the dominant alluvial deposit is medium to fine grained sand with variable content of silt and clay. The thickness of this alluvial deposit ranges from 0.8 to $5 \mathrm{~m}$. In general, due to lack of both extensive areal coverage and significant thickness nature, in comparison with the other dominantly occurring geological formations, the contribution of the sediments as a water-bearing formation is almost negligible.

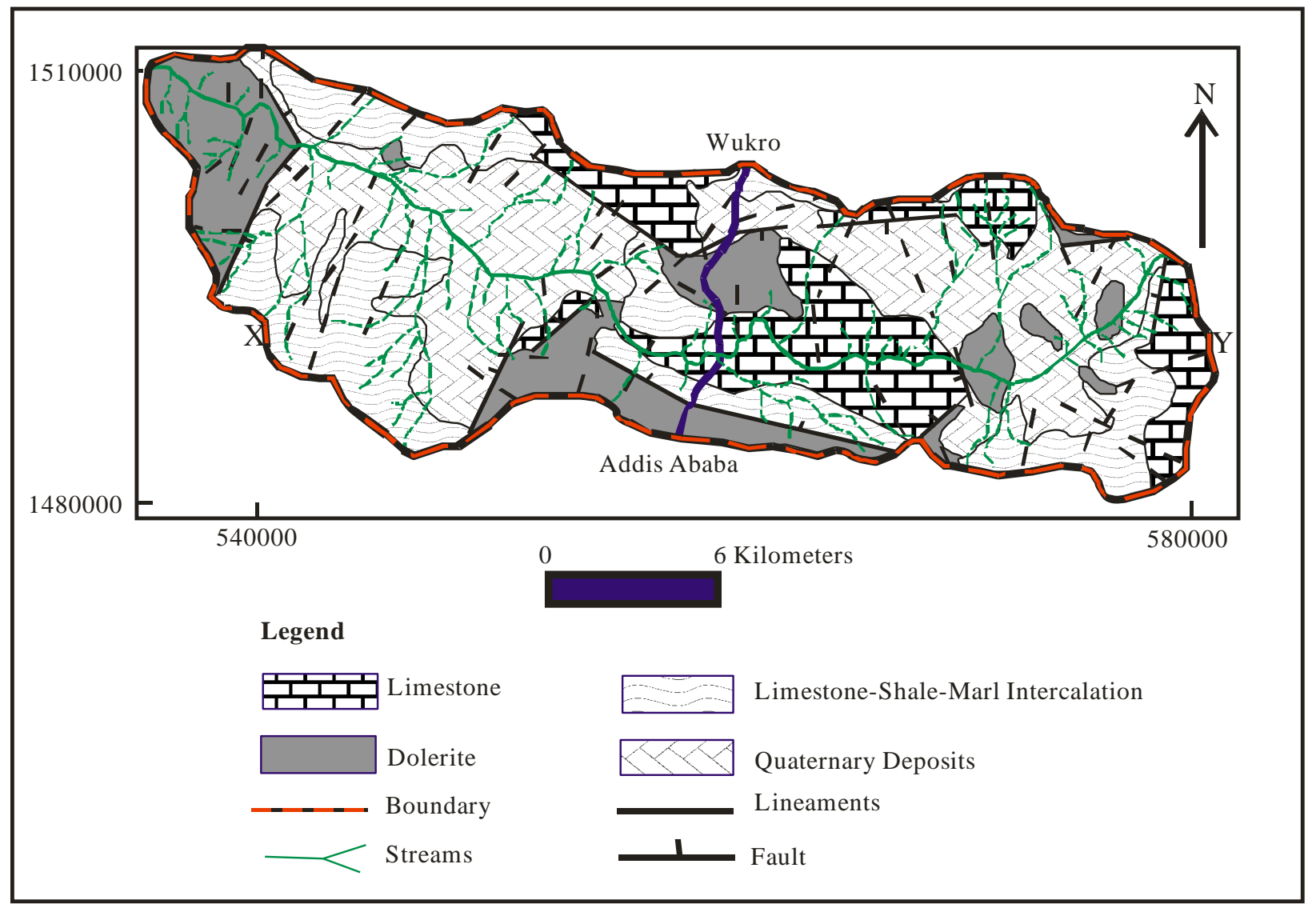

Figure 4. Geological map of the study area (Grmay, 2011). 


\subsection{Geological Structure}

The bedding and primary layers of the rocks in the area are generally flat-lying or moderately tilted. However, the beddings and primary layering display complicated bearings near the dolerite dykes and major fault belts, but these are quite local in extent. The major structure that occurs in the area is fracture, oriented in two main directions. These are mostly sets of conjugate faults oriented in NW-SE and NE-SW directions, dipping toward north and east, respectively. Those oriented in NW direction are particularly concentrated in the Mekelle fault. Faults trending in the NE direction are found widely distributed throughout the area (Fig 4). However, there are two main faults of interesting extent and trend that run west of Mekelle city all the way from Debri village to the northern part, crossing Mesobo hill. In addition to these, there are two other fault trends that run in N-S and E-W directions with very less frequent occurrence. In the Mekelle fault belt there are series of normal faults running at parallel directions on either side of Ellala River, forming something like graben structure. This is particularly well displayed in the upper part of Ellala River, east of Quiha village. Dolerite dykes mark the fault zone of the main Mekelle fault. The dikes have intruded during upliftment and faulting in Cenozoic time (Gebresilassie et al., 2012).

\section{METHODOLOGY}

Geological and hydrogeological methods were employed in this investigation. Extensive work was carried out by collecting both primary data directly from the field and by compiling secondary data from different offices. Lithological boundaries, drainage patterns and geological structures were traced from aerial photographs.

Hydrogeological field investigation was done by giving more attention in differentiating the sediments and rock units of groundwater significance (such as the degree of fracturing of the rock units, space between fractures and opening space of fractures in the rocks, the extent and degree of effect of weathering in the rocks, the type and degree of precipitations of secondary materials in the fractures of the rocks, the thickness of the formations, the grain size, shape, sorting of grains and the clay proportion in the sediments). Inventory of boreholes, shallow wells and springs was conducted as part of the hydrogeological investigation. From the data of the geological logs and hydrogeological field investigations hydrogeological logs were prepared to 
determine different aquifer types in the catchment. Pumping test data of the wells were also collected, analyzed and interpreted to determine the productivity the different aquifer types in the catchment.

In the aquifer potentiality characterization of the aquifer of the catchment, pumping and recovery test data of twenty two wells were analyzed besides to the analysis and interpretation of well logs data and topographic nature of the catchment. The aquifers were characterized in terms of their respective hydraulic conductivity, transmissivity and specific capacity. Of these twenty two wells, ten of them are shallow wells and the remaining twelve are deep wells. Areal distribution point of view three of them are located in the western part, seven are in the northwestern parts, one is in the southwestern, four in the eastern, one is in southern and the remaining six are located in the central parts of the catchment. Out of these 22 wells; 5, 4 and 13 wells are drilled in the limestone, dolerite, and limestone-shale-marl aquifer, respectively. The wells are both partially and fully penetrating wells and the aquifer type at which these wells were drilled are confined and semi-confined.

In the catchment, due to the unavailability of piezometer data, pumping and recovery data were collected from the pumping well itself. However, due to shortcomings inherent in the drawdown data of the pumping well, only the recovery data are used for the analyses of the hydrodynamic properties of the different aquifers of the catchment. These data were analyzed using Theis-Jacob Recovery method, residual drawdown versus ratio $t / t$ '. Analyses of all residual drawdown data have been carried out by Aquifer Test software. The program contains analytical solutions for pumping and slug tests for confined, unconfined, and leaky confined aquifers.

\section{RESULTS AND DISCUSSION}

\subsection{Results}

\subsubsection{Limestone}

The limestone aquifer was characterized by utilizing the available well logs (Fig 5A) data and recovery test data (Fig 6A) besides to field observation. In the catchment, the limestone has appreciable secondary porosity and permeability as a result of weathering, fractures, karsts and openings along bedding planes. It is characterized by the existence of systematic intersecting two sets of vertical joints that have an orientation $\mathrm{S} 35^{\circ} \mathrm{E}$ and are orthogonal to each other. 


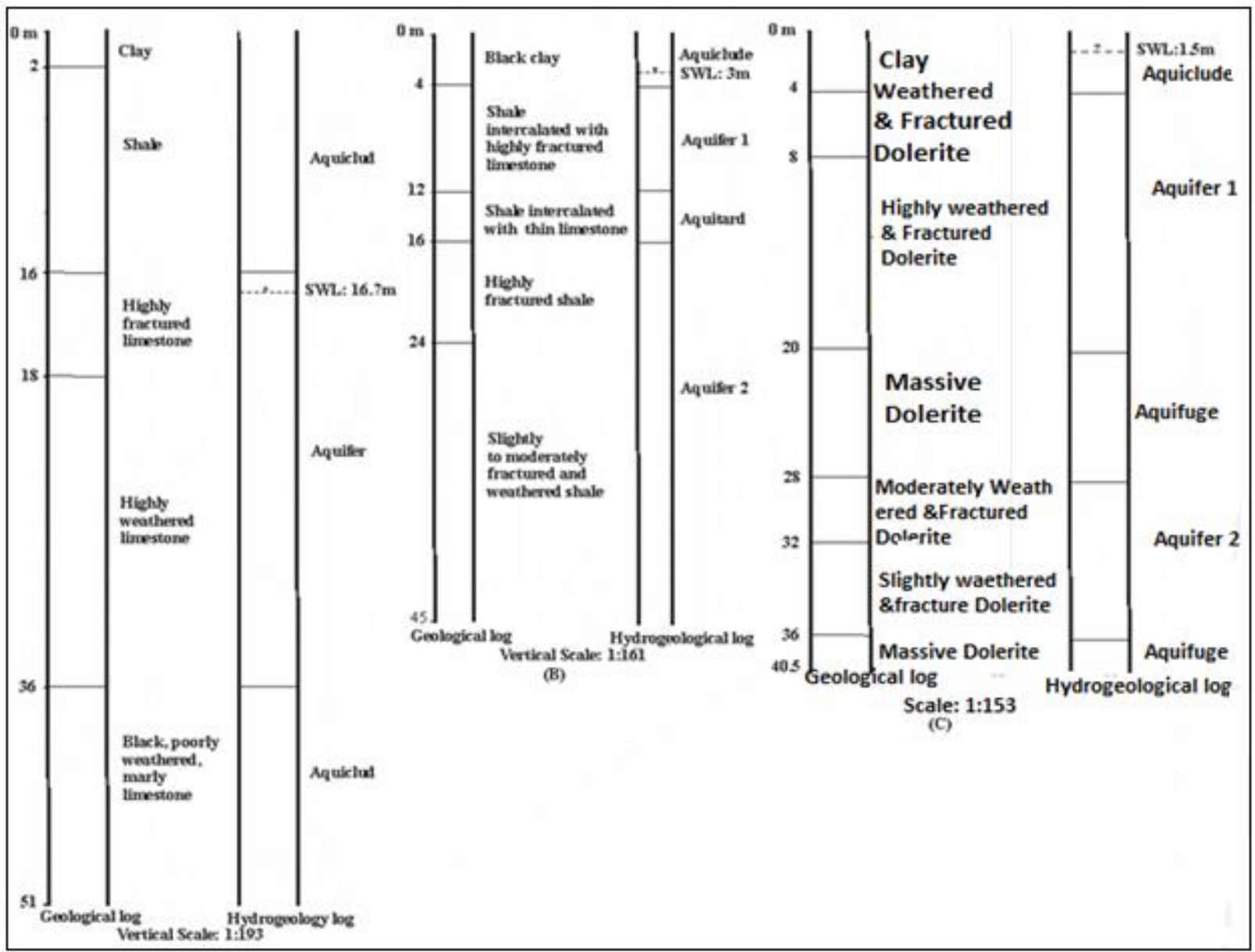

Figure 5. Lithological log and hydrogeological log in a well drilled in (A) limestone aquifer, (B) limestone-shale-marl intercalation aquifer, and (c) dolerite aquifer.

Space between fractures is ranging from $0.4-2 \mathrm{~m}$ having an opening space ranging from 0.6 $10 \mathrm{~cm}$. Some joints are oriented parallel to the trend of the major fault in the catchment. In some places like near to the Arato, the limestone is characterized by having both systematic and nonsystematic intersecting joints. The systematic joints are vertical joints that have a strike of $\mathrm{N} 140^{\circ} \mathrm{W}$ with joint spacing and aperture of ranging from 1.5 to $2 \mathrm{~m}$ and 0.2 to $2 \mathrm{~cm}$, respectively. Moreover, the limestone in this area is also highly karstified. The non- systematic joints are also vertical joints that have an orientation of $\mathrm{S} 30^{\circ} \mathrm{W}$ with joint spacing and aperture varying from 0.5 to $1 \mathrm{~m}$ and 0.2 to $0.6 \mathrm{~cm}$, respectively.

Field observation and geological well logs revealed that, the thickness and physical characteristics as well as areal extent of the weathered and fractured zones of this rock is not uniform throughout the catchment. In general, the weathered and fractured zones are not very 
thick: in surface exposures it is found ranging 3-40 $\mathrm{m}$ whereas in well logs it is found having a range from $20-52 \mathrm{~m}$.

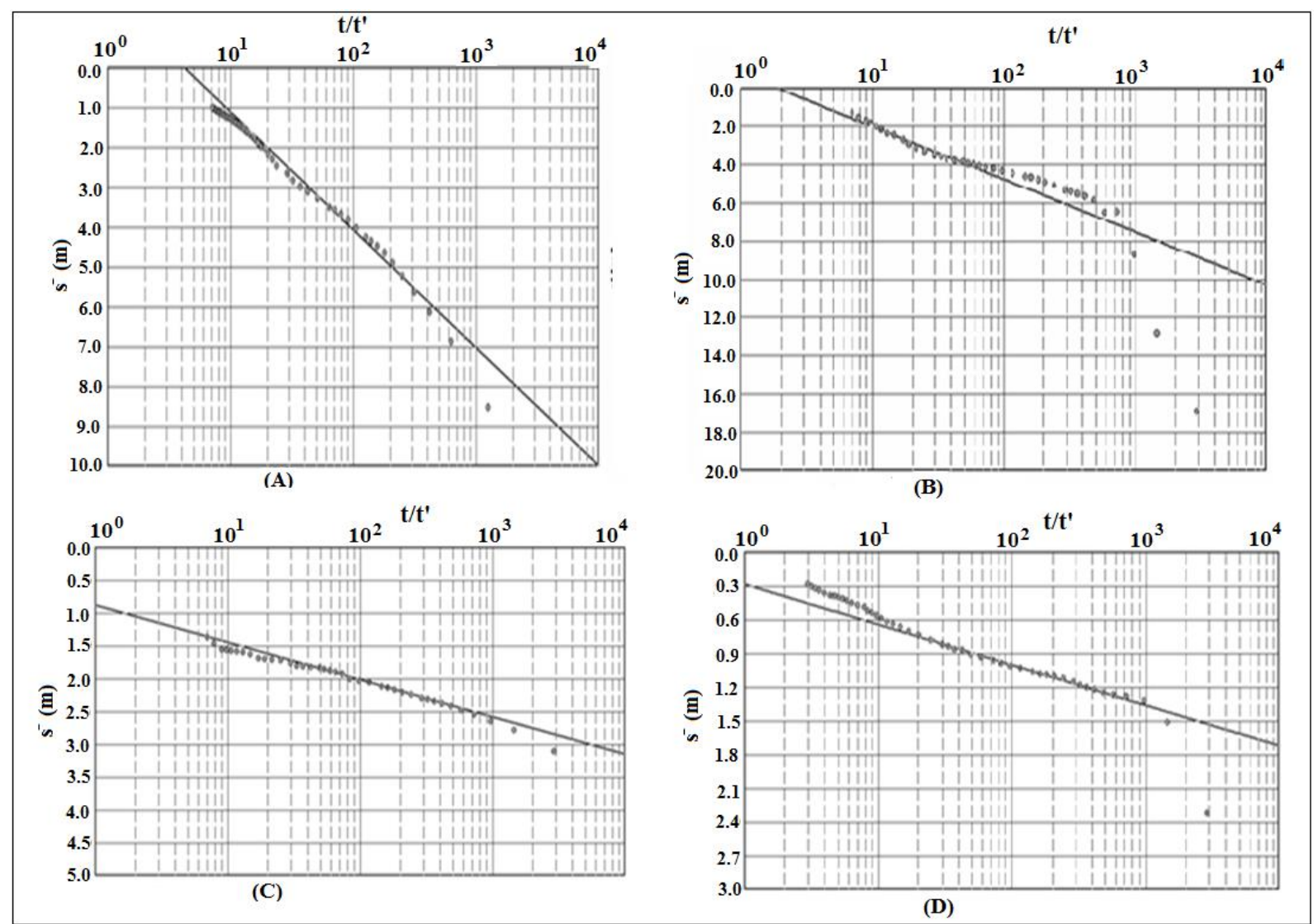

Figure 6. Semilogarithmic plot of residual drawdown versus ratio $t / t^{\prime}$ at the pumping well; $A$ is for SHW63 well (limestone aquifer), B and C for BH-1 and BH-3 wells, respectively, (both wells were drilled in the intercalated limestone-shale-marl aquifer), and D is for SHW58 well (dolerite aquifer).

More than 26 wells are found in this formation with depth ranging from 51 to $204 \mathrm{~m}$ with an average depth of $100 \mathrm{~m}$. The static water level ranges from $3 \mathrm{~m}$ to $21 \mathrm{~m}$ below ground surface with a mean value of $10.53 \mathrm{~m}$. The well yield also ranges from 3 to 12 1/s with a mean value of $5.9 \mathrm{l} / \mathrm{s}$. The drawdown ranges from 5.65 to $45.5 \mathrm{~m}$ with an average value of $23.2 \mathrm{~m}$.

In limestone aquifer, the computed hydraulic conductivity is ranging from 0.046 to $4.65 \mathrm{~m} / \mathrm{day}$ with a mean value of $1.44 \mathrm{~m} /$ day, transmissivity ranging from 2.38 to $93.02 \mathrm{~m}^{2} /$ day with a mean value of $32.58 \mathrm{~m}^{2} / \mathrm{day}$, and specific capacity ranging from 0.1 to $2.12 \mathrm{l} / \mathrm{s} / \mathrm{m}$ with a mean value of $0.57 \mathrm{l} / \mathrm{s} / \mathrm{m}$ (Table 1). Data suggest that groundwater in this unit occurs under unconfined, confined and multilayer confined conditions. 
Table 1. Summarized hydrodynamic values for different aquifers.

\begin{tabular}{|c|c|c|c|c|c|c|c|c|c|c|c|}
\hline No. & Well & $\begin{array}{l}\text { Aquifer - } \\
\text { Geology }\end{array}$ & $\begin{array}{l}E \\
(m)\end{array}$ & $\begin{array}{l}N \\
(m)\end{array}$ & $\begin{array}{l}\text { Thick- } \\
\text { ness } \\
\text { (m) }\end{array}$ & $\begin{array}{l}\text { Depth } \\
\text { (m) }\end{array}$ & $\begin{array}{l}T \text { - } \\
\text { Recovery }\end{array}$ & $\begin{array}{l}\text { K- } \\
\text { Recovery }\end{array}$ & $\begin{array}{l}Q \\
(l / s)\end{array}$ & $\begin{array}{l}D D \\
(m)\end{array}$ & $\begin{array}{l}S c \\
(l / s / m)\end{array}$ \\
\hline 1 & DPW1 & Limestone & 561065 & 1490888 & 51.66 & 128.6 & 2.38 & 0.046 & 4.5 & 45.48 & 0.099 \\
\hline 2 & DPW5 & Limestone & 556322 & 1494784 & 42.6 & 204 & 22.55 & 0.66 & 2.98 & 19.9 & 0.15 \\
\hline 3 & SHW51 & Limestone & 546189 & 1501433 & 19.95 & 57.5 & 93.02 & 4.65 & 12 & 5.65 & 2.12 \\
\hline 4 & SHW60 & Limestone & 563901 & 1495617 & 26.42 & 60 & 18.23 & 0.69 & 5 & 26.93 & 0.186 \\
\hline 5 & SHW63 & Limestone & 564150 & 1491833 & 22.8 & 51 & 26.70 & 1.17 & 5 & 17.81 & 0.281 \\
\hline 6 & BH-1 & L-S-Marl & 550855 & 1500131 & 40.18 & 180 & 117.5 & 2.93 & 20.6 & 31.55 & 0.65 \\
\hline 7 & BH-3 & L-S-Marl & 550855 & 1500131 & 46.92 & 152.6 & 222.05 & 4.85 & 8 & 9.11 & 0.88 \\
\hline 8 & BH-5 & L-S-Marl & 552122 & 1499182 & 23.84 & 100 & 350.8 & 14.7 & 29.3 & 20.11 & 1.46 \\
\hline 9 & Bh-6 & L-S-Marl & 551901 & 1498946 & 34.08 & 110 & 37.24 & 0.873 & 6 & 19.3 & 0.31 \\
\hline 10 & WWNo3 & L-S-Marl & 550604 & 1499441 & 25.49 & 76 & 73.4 & 2.88 & 6 & 5.46 & 1.099 \\
\hline 11 & WWNo4 & L-S-Marl & 551239 & 1499241 & 11.22 & 40.6 & 117.5 & 10.54 & 8 & 4.15 & 1.93 \\
\hline 12 & DPW6 & L-S-Marl & 554758 & 1495612 & 42 & 114 & 311.9 & 7.6 & 5.1 & 1.13 & 4.51 \\
\hline 13 & WWNo6 & L-S-Marl & 550688 & 1498802 & 13.94 & 73 & 17.88 & 1.28 & 4 & 7.04 & 0.57 \\
\hline 14 & DPW3 & L-S-Marl & 552791 & 1497261 & 69 & 146.4 & 30.93 & 1.26 & 10 & 18.98 & 0.53 \\
\hline 15 & DPW4 & L-S-Marl & 552791 & 1497261 & 45 & 145 & 50.976 & 1.08 & 10 & 37.82 & 0.26 \\
\hline 16 & SHW52 & L-S-Marl & 545780 & 1501206 & 19.95 & 60 & 63.65 & 3.2 & 8 & 12.3 & 0.65 \\
\hline 17 & SHW53 & L-S-Marl & 545706 & 1500553 & 19.95 & 47.5 & 645.7 & 70.13 & 12.23 & 5.95 & 2.06 \\
\hline 18 & WH1 & L-S-Marl & 548775 & 14952 & & 138 & 84.76 & & 5 & 23.57 & 0.21 \\
\hline 19 & BH-4 & Dolerite & 549732 & 14979 & 34.44 & 128 & 57.63 & 1.67 & 4.8 & 17.49 & 0.27 \\
\hline 20 & SHW58 & Dolerite & 574606 & 1494548 & 28.1 & 58 & 307 & 108.864 & 7 & 8.72 & 0.25 \\
\hline 21 & SHW45 & Dolerite & 569904 & 1492898 & 31.35 & 64 & 63.504 & 19.613 & 6 & 4.72 & 1.27 \\
\hline 22 & BHmini & Dolerite & 553444 & 1490329 & 39 & 138 & & 107.136 & 13 & 1.65 & 7.88 \\
\hline
\end{tabular}

Note $: \mathrm{T}=\mathrm{m}^{2} /$ day; $\mathrm{K}=\mathrm{m} /$ day; $\mathrm{DD}=$ Drawdown; $\mathrm{Sc}=$ specific capacity;

L-S-Marl = intercalation of limestone-shale-marl.

\subsubsection{Limestone-Shale-Marl Intercalation}

In general this unit is highly affected by different geological structures: major Mekelle fault, other ordinary faults and minor folds, joints, fractures and karsts. The trend of most of these structures is parallel to the surface flow direction but, in some case the joints are oriented orthogonal to each other and with other structures which show more than one sets of joint nature. Some joints and fractures are also found orienting parallel and orthogonal to the strike of the unit. The natures of the joints are both systematic and non-systematic, and generally ranging from one to four sets of joints. The joint spacing and aperture is ranging from 0.5 to $1.5 \mathrm{~m}$ and from $0.1 \mathrm{~cm}$ to $0.6 \mathrm{~m}$, respectively.

Assessment of the hydrogeological characteristics of this unit as a whole was carried out based on the lithological logs (Fig 5B), field observation and available recovery data (Figs 6B \& C). 
Accordingly, this unit has considerable secondary porosity and permeability as a result of weathering and fracturing. However, field observation and geological well logs revealed that, the thickness and physical characteristics as well as areal extent of the weathered and fractured zones of this rock as a whole is not uniform throughout the catchment. Available data revealed that, in general, as a whole unit, the weathered and fractured zones are not very thick: in surface exposures it is found ranging $2-33 \mathrm{~m}$ whereas in well logs it is found having a range from 14$69 \mathrm{~m}$.

\subsubsection{Dolerite}

The dolerite dykes and sills, which usually occur as sills and dykes intruding the limestone and limestone-shale-marl intercalation units of the catchment, do not have the same nature wherever they are found. Well logs that were drilled in these formations and outcropped at the surface revealed that these intrusive bodies are found having a massive and fresh nature and they are also found affected by different degree of weathering, joints and fractures (Fig 5C). The width of the dykes dominantly is ranging from few meters to hundreds of meters whereas in length they vary from a few meters to several kilometers long.

In those dolerite dykes and sills that are affected by joints and fractures, with some exceptions the joints are mostly systematic. The joint spacing and aperture are ranging from $3 \mathrm{~cm}$ to $2 \mathrm{~m}$ and $0.1 \mathrm{~cm}$ to $0.5 \mathrm{~m}$, respectively. The trend of the joints is E-W and N-S ranging from one set to three sets but, some joints are non-measurable which are localized.

Field observation and geological well logs revealed that the thickness and physical characteristics as well as areal extent of the weathered and fractured zones of the dolerite and sill intrusions is not uniform throughout the catchment where these intrusions are found. In general, the weathered and fractured zones are not very thick: in surface exposures it is found ranging 30$75 \mathrm{~m}$ whereas in well logs it is found having a range from $28-39 \mathrm{~m}$.

Available data on the position of the groundwater level in relation to the different layers of these intrusions revealed that groundwater in the dolerite and sill intrusions occurs under confined, multilayer confined and unconfined conditions.

More than 11 wells have been found drilled in this formation. The depth ranges from $58 \mathrm{~m}$ to $138 \mathrm{~m}$ with an average depth of $97 \mathrm{~m}$. The static water level ranges from $5.5 \mathrm{~m}$ to $15 \mathrm{~m}$ below 
ground surface with a mean value of $7 \mathrm{~m}$. The well yield also ranges from 4.8 to $13 \mathrm{l} / \mathrm{s}$ with a mean value of 7.7 1/s. The drawdown ranges from $1.65 \mathrm{~m}$ to $17.5 \mathrm{~m}$ with an average value of $8 \mathrm{~m}$. Besides well logs and field observation, aquifer characterizations of the dolerite aquifers was also done by employing available recovery test data (Fig. 6D). Accordingly, in the dolerite aquifer the computed hydraulic conductivity is ranging from 1.67 to $108.86 \mathrm{~m} /$ day with a mean value of $59.32 \mathrm{~m} /$ day, transmissivity is ranging from 57.63 to $307 \mathrm{~m}^{2} /$ day with a mean value of $142.71 \mathrm{~m}^{2} /$ day, and specific capacity is ranging from 0.25 to $7.88 \mathrm{l} / \mathrm{s} / \mathrm{m}$ with a mean value of $2.42 \mathrm{l} / \mathrm{s} / \mathrm{m}$ (Table 1$)$.

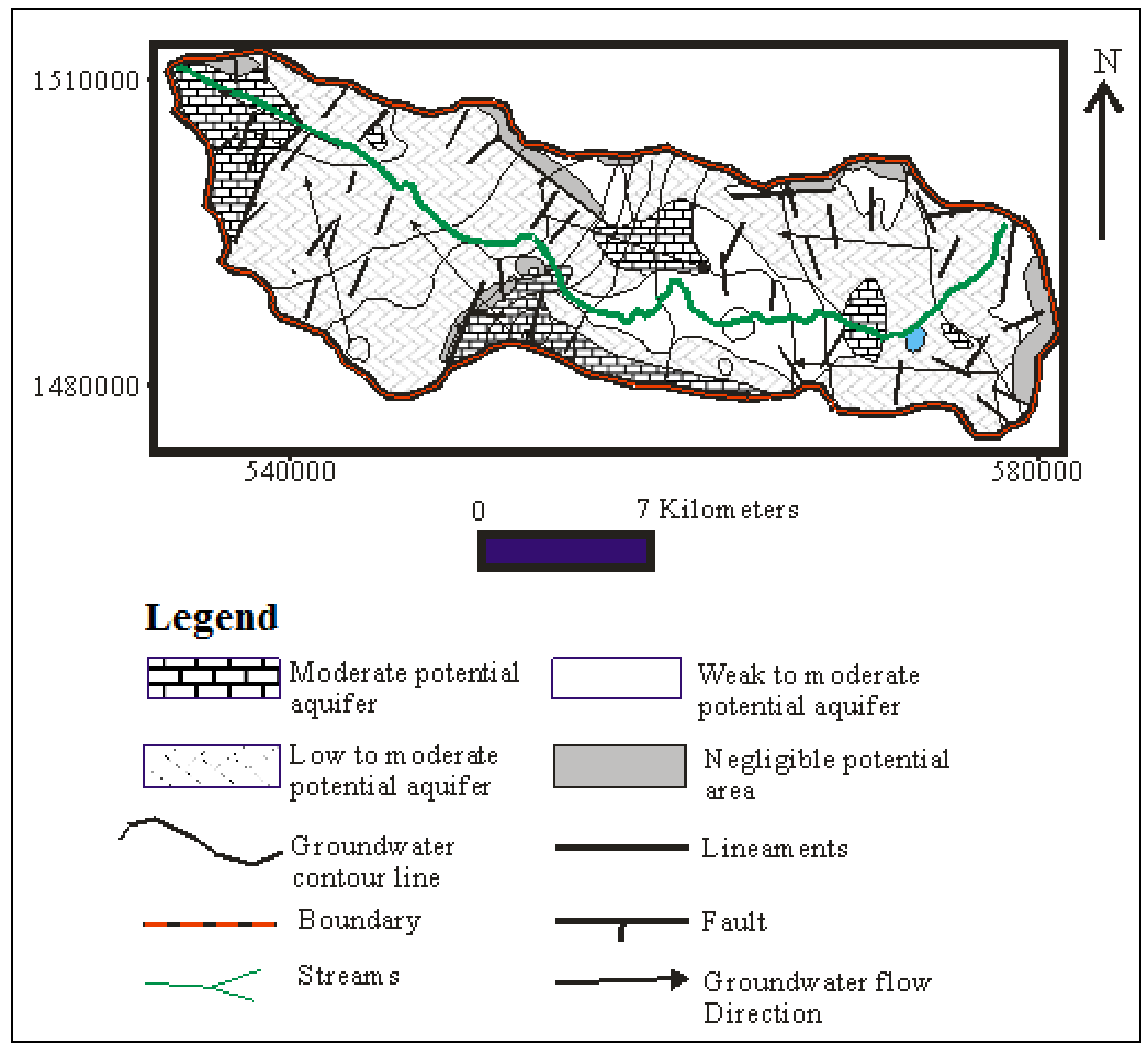

Figure 7. Hydrogeological map of the catchment. 


\subsection{Discussion}

The rocks that constitute the catchment and play the role of an aquifer get their water bearing nature mainly due to secondary processes: fracturing, weathering and karstification processes. Available forty-nine well logs data reveal that the major aquifers in the catchments are fractured, jointed and karstified limestone, weathered and fractured dolerite and limestone-shale-marl intercalation. The hydrogeological map of the study area was produced and is given in figure 7 . In the catchment, the limestone is serving as a fractured rock reservoir. Its degree of groundwater productivity is entirely depends on secondary porosity and permeability that develop as a result of weathering, fracturing, karstification and openings along bedding planes. Due to this its degree of productivity is highly controlled by degree of the effect of fracturing, weathering and karstification besides to the geomorphological position that it occupied.

However, as it is revealed from its productivity analyses, the limestone is found having less productive nature as compared to the other formations in the catchment. This is mainly due to the decrease in the effect of the secondary processes that create conducive environment for water transmission and storage with depth. Even though, limestone is found affected by weathering, fracturing and karstification processes, the effect of all these process are more pronounced at the surface or few tens of meters with depth and become less significant with depth. Fractures tend to close at depth because of vertical and lateral stresses imposed by overburden loads and "locked-in" horizontal stresses of tectonic origin. The fractures are caused by changes in the stress conditions that have occurred during various episodes in the geologic history of the rocks. The intercalated limestone-shale-marl aquifer is the second most productive aquifer in the catchment. The intercalated limestone-shale-marl as one unit as a whole has appreciable secondary porosity and permeability as a result of fractures, karstification and weathering. However, the degree of permeability and productivity of this formation is highly controlled by the nature of the intercalated beds of shale and marl. This is the main reason why this aquifer having such considerable areal extent and thickness could not able to bear significant yield to the wells and become the main productive aquifer in the catchment.

In the area where the intercalated beds of shale and marl have un-fractured and/or un-weathered nature, this nature of the formations reduces its role being as an important aquifer and results yielding of small amount of water to the wells that are drilled on it. The existence of shale and 
marl in this nature reduced the past karstification as well as the present day permeability and productivity of the aquifers. Outside the basin, in the nearby area, it was observed that very large numbers of springs emerge at the contact of the limestone beds with shale's and marls. According to Tesfaye (1993), a few of these springs have large discharges, greater than 10 1/s, but most have moderate or low discharge.

The degree of importunacy of this formation being an aquifer increased and gets better where it contains intercalated beds of weathered shale and marl besides to the geomorphological position where it occupied. Shale in its original forms does not have any significant property of water storage and transmission. Intergranular permeability is low $\left(10^{-13}\right.$ to $\left.10^{-9} \mathrm{~m} / \mathrm{s}\right)$ so that groundwater cannot move faster than a few centimeters per century through intact shale's. However, weathering and fracturing can impart significant secondary porosity and permeability which can enhance its usefulness to the water supply. Therefore, the water-bearing capacity of this rock depends almost entirely on the secondary porosity and permeability that develops as a result of fracturing and also weathering.

In the dolerite dykes and sills, the degree of fracturing and weathering is high and this results this unit to have well pronounced secondary porosity and permeability that makes them the main productive aquifer as compared it to the other units that are found in the catchment. This is also confirmed by the results of the hydrodynamic properties of the aquifers. The analyses of the recovery data of the wells indicate that the highest hydraulic conductivity is obtained in the dolerite aquifer whereas the lowest value is corresponding to the limestone aquifer. The determined transmissivity value is also revealed that the potentiality of the dolerite aquifer is moderate whereas as the other aquifers are ranging from moderate to weak.

Even though the dolerite aquifer is the major productive aquifer in the catchment, however, its degree of productivity is limited with decrease in the effect of weathering and fracturing with depth. The massive dolerite dykes and sills are an aquifuges. As dykes are usually more resistant to erosion than the country rock they stand out prominently as wall-like ridges. Massive and unweathered dykes form barriers for lateral movement of groundwater, thereby confining large volumes of groundwater. On the other hand, fractured and weathered dolerite dykes may form good aquifers. Depending on its width and thickness, fractured and weathered dolerite dyke can 
form potential source of groundwater. Just like that of dolerite dykes, only fractured and weathered dolerite sills can form potential aquifers.

\section{CONCLUSION AND RECOMMENDATION}

The different rocks and sediment that constitutes the geology of the catchment are limestone, limestone-shale-marl intercalation, dolerite dykes and sills intrusions and recent sediments. These rocks and sediments are found covering the catchment having different areal distribution and thickness.

Since the catchment is dominated by rocks of different types ( 80 per cent of the total study area) and extensive sediments with significant thickness are not found, the sediments are found having no hydrogeological significance whereas the rocks are serving as a water bearing formations having different productivity nature. These rocks get their being a water bearing nature mainly due to secondary processes: fracturing, weathering and karstification processes. The rocks vary in their respective groundwater productivity nature primarily because of the difference in the degree of the effect of fracturing, weathering and karstification processes. These three secondary processes are dominantly found in the limestone and in the intercalated limestone-shale-marl units whereas fracturing and weathering are the major processes that affect dolerite dykes and sills. Primary porosity and permeability are found having no significance in the rocks of the catchment.

Based on Şen (1995) classification scheme, which takes into account the transmissivity values, the potentiality aquifers of the catchment is ranging from moderate to weak; dolerite aquifer is moderate; intercalated limestone-shale-marl aquifer is from moderate to low; and, limestone aquifer is from moderate to weak. Negligible potentiality aquifer is found covering steep slope and topographically high areas. The transmissivity values are also confirmed by the hydraulic conductivity values where the highest hydraulic conductivity value is in the doleritic aquifer followed by the intercalated limestone-shale-marl. The limestone aquifer is the one that has the least hydraulic conductivity value. The transmissivity values show a kind of increasing along the flow path of the groundwater that show a parallel trend of conduit fractures and joints with the major fault in the subsurface. 
Based on Şen (1995) classification scheme that takes into account specific capacity values, the productivity of wells in the catchment ranges from high to low productivity: $4.17 \%$ of the well indicates high productive, $58.33 \%$ of the wells indicate moderately productivity nature and $37.5 \%$ of the wells depict low productivity nature.

All the pumping test data were collected from pumping well itself. Utilization of observation wells in the determination of the aquifer hydraulic properties, which is very important in the understanding of the real groundwater potential of the aquifers, is not a common practice in the groundwater development of the area. Since the data that are collected in the pumping well is inherited with error due to well loss, utilization of observation wells data are highly recommended for a better understanding of the groundwater productivity of the different aquifers of the catchment. Development of groundwater for multi-purposes in the catchment like Ellala is very essential. However, together with this management investigation has to be done so that the resources can be utilized sustainably for long period of time.

\section{ACKNOWLEDGEMENTS}

VLIR-Institutional University Cooperation - Mekelle University (IUC-MU) project is duly acknowledged for funding this research project.

\section{REFERENCE}

Fetter, C.W. 2001. Applied Hydrogeology. 4th edition, Prentice-Hall, New Jersey, USA.

Gebresilassie, Solomon., Bheemalingeswara, Konka \& Fiseha Adhanom. 2012. Geology and Characteristics of Metalimestone-hosted Iron Deposit near Negash, Tigray and Northern Ethiopia. International Journal of Earth Sciences and Engineering, 5(6):1535 - 1544.

Grmay Kassa. 2011. Aquifer characterization and groundwater quality evaluation for irrigation purpose: a case study in Ellala catchment, northern Ethiopia. M.Sc thesis, Department of Earth Science, Mekelle University, Mekelle, Ethiopia (unpubl.).

Mace, R.E.,1997. Determination of transmissivityfrom specific capacity tests in karestic aquifer. Groundwater, 35:738-742.

Matthess, G, 1982. The properties of groundwater, John Wiley, New York. 
Ministry of Water Resources. 2001. Initial national communication of Ethiopia to the United Nations Framework Convention on Climate Change (UNFCCC). A report submitted to the conference of parties of the UNFCCC under the GEF support Climate Change Enabling Activities Project of Ethiopia, Ministry of water resources, Addis Ababa, Ethiopia.

Nata Tadesse. 2003. Hydrogeological investigation and environmentally sound plans for the development of groundwater in the Weri River Basin, Tigray, Ethiopia. Ph.D. diss., Institutes of Applied Geology, University of Natural Resources and Applied Life Sciences (BOKU) Vienna, Vienna (unpubl.).

Nata, T., Bheemalingeswara, K \& Asmelash, B. 2009. Groundwater suitability for irrigation purpose: a Case study from Debre Kidane watershed, eastern Tigray, Ethiopia. Momona Ethiopian Journal of Science, 1(1):36-59.

Nata, T \& Bheemalingeswara, K. 2010. Prospects and Constraints of Household Irrigation Practices, Hayelom Watershed, Tigray, Northern Ethiopia. Momona Ethiopian Journal of Science, 2(2):87-109.

Nedaw, D. 2003. Aquifer characterization and hydrochemical investigation in the Raya Valley, Northern Ethiopia. PhD thesis. University of Natural Resources and Applied Life Sciences, Department of Applied Geology, Boku, Vienna. 248p.

Singhal, B.B.S \& Gupta, R.P. 1999. Applied Hydrogeology of Fractured Rocks, Kluwer Academic Publishers, Dordrecht.

Şen, Z. 1995. Applied Hydrogeology, CRC Press, Inc., Boca Raton.

Tesfaye Chernet. 1993. Hydrogeology of Ethiopia and Water Resources Development, E.I.G.S., Addis Ababa, 222p. 